\title{
Analisis gaya kepemimpinan terhadap kedisiplinan dan kinerja guru sekolah menengah kejuruan
}

\author{
Ade Satria *, Siti Maryam \\ Program Studi Ilmu Pemerintahan Fakultas Ilmu Sosial dan Ilmu Politik, Universitas Muara Bungo \\ Jalan Diponegoro No. 27, Muara Bungo-Jambi, Indonesia \\ * Corresponding Author. E-Mail: adesatriaumb@gmail.com
}

\begin{tabular}{ll}
\hline \hline \multicolumn{1}{c}{ Info Artikel } & \multicolumn{1}{c}{ Abstrak } \\
\hline \hline Histori Artikel: & Tujuan penelitian adalah untuk mengetahui Gaya kepemimpinan Kepala Sekolah \\
Received: 9 Dec. 2019 & Terhadap Kedisiplinan dan Kinerja Guru SMK Negeri 3 Muara Bungo mengetahui \\
Revision: 18 Dec. 2019 & hambatan dan mengetahui Pengaruh Gaya kepemimpinan terhadap kedisiplinan Guru \\
Accepted: 31 Dec. 2019 & di SMKN 3 Muara Bungo. Metode yang digunakan dalam penelitian ini adalah metode \\
Kata Kunci: model & deskriptif kualitatif. populasi dalam penelitian ini adalah Kepala Sekolah dan Guru \\
gaya kepemimpinan; & SMKN 3 Muara Bungo. Jumlah sampel ditetapkan dalam penelitian ini berjumlah 9 \\
kedisiplinan; kinerja & (sembilan) orang. Teknik pengumpulan data yang digunakan adalah data menggunan \\
guru; leadership style; & teknik dengan sumber pustaka dan lapangan (observasi atau wawancara). Berdasarkan \\
discipline; teacher & uraian dan pembahasan yang telah dilakukan tentang Gaya kepemimpinan Kepala \\
performance & Sekolah Terhadap Kedisiplinan dan Kinerja Guru SMK Negeri 3 Muara Bungo masih \\
& belum optimal dalam Upaya kepemimpinan Mempengaruhi Guru Dalam Meningkat- \\
& kan Disiplin Kinerja Guru di SMK Negeri 3 Muara Bungo.adalah dengan melakukan \\
& pendekatan secara personal, melalui komunikasi yang baik serta memberikan motivasi \\
& kemudian bimbingan dan kesempatan kepada guru untuk dapat menunjukan \\
& kemampuannya jika diberi tugas dan tanggung jawab dan selalu patuh terhadap aturan \\
& yang telah dibuat bersama, Upaya dalam mengatasi hambatan tersebut seperti, \\
& kedisiplinan dan kinerja Guru SMK N 3 Muara Bungo.karakter guru yang berbeda- \\
& beda, ada yang rajin, dan komitmen terhadap aturan yang telah dibuat Bersama. \\
\hline \hline
\end{tabular}

The purpose of this study was to determine the Principal's leadership style of Discipline and Teacher Performance in SMK Negeri 3 Muara Bungo, to know the obstacles and to know the Effect of Leadership Style on Teacher discipline at SMK 3 Muara Bungo. The method used in this research is descriptive qualitative method. The population in this study was the Principal and Teacher of SMK 3 Muara Bungo. The number of samples determined in this study amounted to 9 (nine) people. Data collection techniques used are data using techniques with library and field sources (observation or interviews). Based on the description and discussion that has been done about the Principal's leadership style Toward Discipline and Performance of Teachers of State Vocational School 3 Muara Bungo is still not optimal in the leadership effort Influencing Teachers in Improving Teacher Performance Discipline in State Vocational School 3 Muara Bungo. good communication and provide motivation then guidance and opportunities for teachers to be able to show their ability if given the duties and responsibilities and always obey the rules that have been made together, Efforts in overcoming these obstacles such as, discipline and performance of Teachers of SMK N 3 Muara Bungo. different teachers, some are diligent, and committed to the rules that have been made together.

This work is licensed under a Creative Commons Attribution-ShareAlike 4.0 International License.

\section{PENDAHULUAN}

Pada saat sekarang sumber daya manusia baik swasta maupun negeri berusaha mengungkapkan manusia seutuhnya dalam konsepsi pembangunan bangsa yang utuh dan menyeluruh masalah-masalah yang di hadapi Pendidikan swasta maupun negeri dan semakin tingginya tingkat pendidikan Indonesia merupakan paling mendasar dan paling penting dalam kehidupan manusia. Hal ini juga berlaku di Negara Indonesia dimana pendidikan dijamin dan diatur oleh pemerintahan Indonesia. Hal ini sesuai dengan cita-cita bangsa Indonesia yang tercantum dalam UUD tahun 1945: "Mencerdaskan kehidupan 
bangsa" tidak hanya itu, di dalam UUD 1945 Amademen ke -IV (2002) pasal 31 ayat 1 yang berbunyi dengan banyak jaminan hukum mengenai pendidikan (Republik Indonesia, 2002), maka sepatutnyalah warga Negara Indonesia bisa mendapatkan pendidikan yang layak sehingga martabat bangsa ini bisa terangkat berpijak pentingnya pendidikan dan adanya jaminana pendidikan di Indonesia, maka banyak sekali bermunculan sekolah-sekolah baik swasta, negeri, maupun internasional yang tumbuh di negeri ini yang menawarkan beraneka ragam warna, pendidikan, biaya, fasilitas, dan lain-lain sehingga bagi sekolah-sekolah yang tidak mampu memberikan hasil-hasil yang terbaik bagi anak didiknya. Hal ini lah yang mendasari penulis tertarik untuk melakukan sebuah penelitian di lingkungan sekolah yang berada di kabupaten Bungo Jambi yang merupakan salah satu kota pemekaran di kabupaten Muara Bungo yang memiliki sekolah yang unggul di bidang pendidikan. Oleh karna itu penulis mencoba melakukan penelitian di sebuah SMK Negeri 3 Muara Bungo yang berada di Kabupaten Muara Bungo karena merupakan sekolah kejuraan ketiga yang berdiri di desa Talang Pantai dan satu satu nya SMK kejuruan tata busana, tata boga dan multimedia dan menjadi sekolah unggulan di masa sekarang.

Tentunya dengan bergesernya waktu dan teknologi serta kinerja guru meningkatkan mutu pendidikan harus ditunjang dengan kemampuan melaksanakan pokok dan fungsinya secara profesiaonal. Salah satu komponen menarik adalah guru. Terutama pada peningkatan kualifikasi akademiknya, kompetensi dan kineja dalam menjalankan tugas, serta tanggung jawab yang diemban oleh guru sebagai pendidik Upaya untuk mewujudkan mutu guru sesuai dengan Undang-Undang Republik Indonesia Nomor 20 Tahun 2003 pasal 3 ayat (6) bahwa pendidikan diselengarakan sebagai satuan proses pembudayaan dan perdayaan peserta didik yang berlansung sepanjang hayat (Presiden Republik Indonesia, 2003). Tentang Sistem Pendidikan Nasional, bahwa jabatan guru sebagai tenaga pendidik merupakan jabatan professional, untuk itu profesi guru dituntut memiliki tenaga kerja yang prefesiaonal untuk terus berkembang sesuai dengan perkembangan zaman. Oleh karena itu untuk mencapai tingkat pendidikan yang tinggi diperlukan system pendidikan yang profesianal dan mampu menjalani tugas, serta fungsinya sesuai dengan tujuannya perlu didukung oleh tenaga pendidik, yaitu guru professional yang ditentukan oleh kinerjanya.

Kinerja guru akan bermakna, bila dibarengi dengan niat yang tulus, bersih, iklas, dengan menyadari akan kekurangan yang ada pada dirinya dan berupa untuk meningkatkan ke arah yang lebih baik. Kinerja guru dipandang sangat penting karena kemampuan, serta energy positif dimilikinya demi mencapai kinerja yang optimal. Pada akhirnya guru yang berkerja secara optimal dapat menunjang peningkatan mutu pendidikan di sekolah (Suryonsubroto, 2009).

Berdasarkan guru yang mengajar di SMK Negeri 3 Muara Bungo penting bagi guru-guru dan staff untuk meningkatkan kedisiplinan dikarenakan hal ini akan menjadi contoh bagi siswa-siswi disekolah tersebut, membahas soal kedisiplinan hal ini pasti akan berkaitan dengan absensi guru atau tingkat kehadiran dari guru-guru terbukti dimana berdasarkan data absensi tahun 2018 tercatat absensi atau kehadiran guru-guru dan staff disekolah mencapai rata-rata $90 \%$ tingkat kehadiran atau absensi guru disekolah tersebut, hal tersebut mencerminkan tingkat kedisiplinan berkaitan dengan absensi guru cukup baik tetapi hal itu perlu ditingkatkan agar kinerja guru-guru tersebut akan semakin baik.

Kepemimpinan merupakan interaksi antara anggota suatu kelompok sehingga pemimpin merupakan agen pembaharu, agen perubahan, orang yang prilakunya akan lebih mempengaruhi orang lain dari prilaku orng lain yang mempengaruhi prilaku mereka, dan kepemimpinan itu sendiri timbul ketika suatu anggota kelompok menggubah motivasi kepemimpinan itu sendiri timbul ketika suatu anggota kelompok menggubah motivasi kepentingan anggota lainya dalam kelompok (Winardi, 2004).

Pendapat di atas dipertegas juga bahwa kepemimpinan adalah kemampuan dalam melibatkan seorang untuk mempengaruhi orang lain. Untuk dapat mempengaruhi orang lain. Seseorang harus memepunyai kekuasaan digiringkan (power) karena dengan dimiliki power atau kekuasaan tersebut, seseorang dapat mengarahkan dan mempengaruhi bawahan agar bersedia melaksanakan tugas-tugas sebagaimana mestinya.

Kinerja guru menjadi kunci dalam peningkatan mutu pembelajaran, karena guru berada pada from terdepan di titik sentral dari setiap usaha reformasi pendidikan yang diarahkan pada perubahanperubahan kualitatif. Setiap usaha peningkatan mutu kinerja guru tidak terlepas dari perubahan kurikulum, pengembangan metode-metode pembelajaran, penyediaan sarana prasarana. Hasil pengamatan yang dilakukan di SMKN 3 Muara Bungo, tampak Kepemimpinan yang belum efektif di SMKN 3 Muara Bungo, Fungsi kepemimpinan tidak berjalan dengan baik, Tingkat disiplinan guru 
Jurnal Politik dan Pemerintah Daerah, 1 (2), 2019 - 76

Ade Satria, Siti Maryam

dalam berkerja masih sangat rendah, Guru dalam menggunakan media pembelajaran kurang relevan, dan Kinerja guru yang belum maksimal.

\section{METODE}

Penelitian ini dilakukan di salah Satu Sekolah yang ada di Kabupaten Bungo Yaitu di SMK N 3 Muara Bungo Provinsi Jambi, karna di SMK Negeri 3 Muara Bungo Gaya Kepemimpinannya Belum efektif dan belum selayak nya seorang pemimpin, Waktu Penelitian dilakukan selama 4 (Empat) Bulan di mulai Tanggal, 6 Januari 2018 sampai dengan Selesai.

Metode penelitian merupakan cara ilmiah untuk mendapatkan data dengan tujuan dan kegunaan tertentu. Metode Penelitian adalah metode yang digunakan dalam aktivitas ilmiah untuk memperoleh data dengan tujuan dan kegunaan tertentu (Sugiyono, 2009). Secara umum, data yang telah diperoleh dari penelitian dapat digunakan untuk memahami, memecahkan, dan mengantisipasi masalah. Memahami berarti menjelaskan suatu masalah atau informasi yang tidak diketahui sehingga memberikan kejelasan yang akurat dan valid. Metode penelitian adalah memecahkan berarti mengupayakan agar tidak terjadi masalah (Kuswana, 2011, p. 13).

Jenis penelitian ini adalah deskriptif kualitatif, penelitiandeskriptif merupakan prosedur penelitian yang menghasilkan data deskriptif berupa kata-kata tertulis atau lisan dari orang-orang dan perilaku yang diamati. Penelitian deskriptif bermaksud untuk membuat penggambaran secara sistematis, faktual, dan akurat mengenai fakta-fakta dan sifat-sifat populasi tertentu, kemudian berusaha menganalisa dan menjelaskan fenomena-fenomena yang terjadi untuk pemecahan masalah mengenai fakta-fakta dan sifat-sifat dari populasi, serta mendapatkan gambaran tentang permasalahan yang terjadi pada tempat dan waktu tertentu, kemudian berusaha menganalisis dan menjelaskan fenomena-fenomena yang terjadi untuk pemecahan masalah mengenai fakta-fakta dan sifat-sifat populasi.

\section{Teknik Pegumpulan Data}

Teknik pengumpulan data dengan menggunakan instrumen non tes berupa kuesioner. instrumen disusun secara konstruk yang meliputi dua variabel yaitu Kinerja Guru (Y), Gaya Kepemimpinan $\left(\mathrm{X}_{1}\right)$, kedisiplinan $\left(\mathrm{X}_{2}\right)$. Dalam penelitian yangakan dilakukan, penulis menggunakan teknik pengumpulan data melalui studi kepustakaan dan studi lapangan.

Studi Pustaka (Library Research)

Studi pustaka ini dilakukan untuk mendapatkan data teoritis dari berbagai pendapat para ahli dengan cara mempelajari dan menganalisa teori-teori dan peraturan-peraturan yang berhubungan dengan permasalahan yang akan dibahas dan serta dokumen-dokumen lain yang ada kaitannya dengan masalah yang akan diteliti (Kuswana, 2011, p. 200).

\section{Studi Lapangan (Field Research)}

Studi lapangan dilakukan untuk mengumpulkan data primer melalui wawancara, observasi, dokumentasi:

Wawancara

Wawancara adalah komunikasi langsung antara pewawancara dengan responden dalam rangka pengumpulan data (Kuswana, 2011, p. 203). Wawancara bentuk komunikasi antara dua orang, melibatkan seseorang yang ingin memperoleh informasi dari seseorang lainnya dengan mengajukan pertanyaan-pertanyaan berdasarkan tujuan tertentu (Mulyana, 2010, p. 180).

\section{Observasi}

Observasi adalah suatu proses pengamatan terhadap fonemena-fenomena yang terjadi dan berkembang dimasyarakat (Mulyana, 2010, p. 204). Obsevasi merupakan suatu teknik atau cara mengumpulkan data dengan jalan mengadakan pengamatan terhadap kegiatan yang sedang berlangsung (Sukmadinata, 2009, p. 220). 
Dokumentasi

Dokumentasi adalah sebuah cara yang dilakukan untuk menyediakan dokumen-dokumen dengan menggunakan bukti yang akurat dari pencatatansumber-sumber informasi. Dokumentasi digunakan untuk mendapatkan keterangan dan penerangan pengatahuan bukti dalam bentuk sebuah pertanggung jawaban. Dokumentasi adalah metode pengumpulan data dengan cara membaca dan mengutip dokumen-dokumen yang dipandang relevan dengan permasalahan yang diteliti (Arikunto, 2009).

\section{Teknik Penentuan Informan}

Pada penelitian ini teknik penentuan informan yang digunakan adalah Purposive Sampling. Purposive Sampling adalah teknik pengambilan sampel sumber data dengan pertimbangan tertentu, seperti yang dimaksud orang tersebut dianggap paling tahu tentang apa yang kita harapkan dalam penelitian, atau mungkin dia sebagai penguasa sehingga akan memudahkan penelitian menjelajahi objek penelitian. Informan yang di pilih sebagai sumber informasi dikategorikan seperti pada Tabel 1.

Tabel 1. Informan Penelitian

\begin{tabular}{lllc}
\hline No. & \multicolumn{1}{c}{ Nama } & \multicolumn{1}{c}{ Pekerjaan } & Jumlah \\
\hline 1. & Ir.Sepriadi Erman., M.Si & Kepala Sekolah & 1 \\
2. & Elidayanti.M, S.Pd & Wakil Kepala Sekolah Bidang Kesiswaan & 1 \\
3. & Mashuri, S.Pd & Wakil Kepala Sekolah Bidang Kurikulum & 1 \\
4. & Lisda Nazif, S.Pd & Ketua Program Multimedia & 1 \\
5. & Dinda Emilia Triyanti, S.Pd & Ketua Program Tata Busana & 1 \\
6. & Dwi Sulistiawati Putri,S.Pd & Ketua Program Tata Boga & 1 \\
7. & Mohd.Jamil, S.Ag & Kasubag Tata Usaha & 1 \\
8. & Rekha Bianti, S.Sos & Staf Tata Usaha & 1 \\
9. & M.Lazimin & Siswa & 1 \\
& JUMLAH & & 9 \\
\hline
\end{tabular}

\section{Analisis Data}

Setelah melakukan pengumpulan data secara lengkap, maka langkah selanjutnya yang sangat penting untuk dilakukan adalah menganalisa data. Sesuai dengan metode penelitian yang digunakan, maka proses analisis data menggunakan teknik deskriftif kualitatif. Dengan rincian, maka langkahlangkah atau tahapan menganalisis data dalam penelitian adalah sebagai berikut: (1) Mengumpulkan data yang berhubungan dengan penelitian; (2) Pemeriksaan data yang didapat apakah sesuai dengan yang diharapkan; (3) Pengelompokan data-data guna untuk menjawab pertanyaan terhadap suatu penelitian; (4) Melaksanakan pembahasan dan perumusan terhadap data yang didapat; dan (5) Mengambil kesimpulan akhir terhadap data yang diteliti (Sukmadinata, 2009).

\section{HASIL DAN PEMBAHASAN}

\section{Apa Gaya Kepemimpinan Kepala Sekolah SMK Negeri 3 Muara Bungo dalam meningkatkan kinerja guru}

Kepemimpinan adalah proses mempengaruhi dan menterjemahkan keinginan-keinginan para angota atau pengikut yang menekankan pada tujuan dan sasaran organisasi melalui kegiatan memberi motivasi, memelihara hubungan kerjasama yang baik dengan anggota dan memberi dukungan pada kelompok-kelompok tertentu diluar organisasi dan di dalam organisasi.

Hal-hal penting yang perlu dicatat mengenai komponen kepemimpinan pendidikan adalah (1) proses rangkaian tindakan dalam sistem pendidikan; (2) mempengaruhi dan memberi teladan; (3) memberi perintah dengan cara persuasi dan manusiawi tetapi tetap menjunjung tinggi disiplin dan aturan yang dipedomani; (4) pengikut mematuhi perintah sesuai kewenangan masing-masing; (5) menggunakan, authority dan power dala batas yang dibenarkan; dan (6) menggerakkan atau mengerahkan semua personel dalam institusi guna menyelesaikan tugas sehingga tercapai tujuan, meningkatkan hubungan kerja di antara personel, membina kerjasama, menggerakkan sumberdaya organisasi, dan memberi motivasi kerja.

Untuk memenuhi kriteria kepemimpinan tersebut diperlukan: (1) kepemimpinan yang visioner agar penyelenggaraan pendidikan mampu merespon kemajuan ilmu pengetahuan dan teknologi 
Jurnal Politik dan Pemerintah Daerah, 1 (2), 2019 - 78

Ade Satria, Siti Maryam

sebagai upaya membangun sumberdaya manusia yang berkualitas dan kompetitif; (2) kepemimpinan yang efektif daram penentuan kebijakan agar proses pembelajaran yang diselenggarakan pada satuan pendidikan dapat memberi jaminan proses pelayanan belajar yang berkualitas dan juga mutu lulusan yang kompetitif; (3) ketepatan pemimpin dalam mengambil keputusan agar semua keputusan yang diambil adalah keputusan yang dibutuhkan, bukan atas keinginan pihak pengambil keputusan; (4) pendelegasian agar pembagian tugas dalam mensiasati pencapaian target dapat lebih lincah dan lebih terukur sehingga target dapat dipenuhi sesuai dengan yang ditetapkan; dan (5) sikap demokratik yang dikembangkan pemimpin agar terjaga kebersamaan dan semangat yang sama untuk memperoleh keberhasilan dan kesusksesan yang maksimal.

"Wawancara Menurut mashuri bahwa kepemimpinan kepala sekolah di SMKN 3 Muara Bungo masih kurang efektif dan tidak terjadinya sinkronisasi terhadap pemimpin dan kinerja guru sehingga kepemimpin tidak ada perubahan yang lebih baik terhadap guru sehingga banyak guru yang terlambat. ${ }^{1}$

Berdasarkan hasil wawancara tersebut dapat disimpulkan bahwa Kepemimpinan Kepala Sekolah masih kurang efektif dan sehingga tidak singkron antara kepemimpinan kepala sekolah dan kinerja guru sehingga banyak kendala bagi guru sehingga belum optimal.

Karakteristik perilaku gaya kepemimpinan yang berorientasi pada tugas adalah melakukan komunikasi satu arah, menyusun rencana kerja, merancang tugas-tugas, menetapkan prosedur kerja dan menekankan pencapaian tujuan organisasi. Sedangkan karakteristik perilaku gaya kepemimpinan yang berorientasi pada hubungan manusia adalah menjalin hubungan akrab, menghargai anggota, bersikap hangat, dan menaruh kepercayaan kepada anggota.

Berdasarkan dua orientasi kepemimpinan tersebut, selanjutnya gaya kepemimpinan bisa diklasifikasi menjadi empat, yaitu: (1) Task oriented leadership, yakni gaya kepemimpinan yang berorientasi tinggi pada tugas, dan rendah pada hubungan manusia (2) Relationship oriented leadership, yakni gaya kepemimpinan yang berorientasi tinggi pada hubungan manusia, tetapi rendah pada tugas, (3) Integrated leadership, yakni gaya kepemimpinan yang berorientasi tinggi pada tugas dan hubungan manusia, dan (4) Impoverished leadership, yakni gaya kepemimpinan yang berorientasi rendah pada tugas dan hubungan manusia

Kepemimpinan yang efektif adalah perilaku kepemimpinan yang sesuai dengan karakteristik organisasi, terutama kondisi kematangan bawahan. Terdapat indikator-indikator kepemimpinan yang efektif sebagai berikut; (1) Menerapkan pendekatan kepemimpinan partisipatif terutama dalam proses pengambilan keputusan; (2) Memiliki gaya kepemimpinan yang demokratis, lugas, dan terbuka; (3) Menyiapkan waktu untuk berkomunikasi secara terbuka dengan para guru, peserta didik, dan warga sekolah lainnya; (4) Menekankan kepada guru dan seluruh warga sekolah untuk memenuhi normanorma pembelajaran dengan disiplin yang tinggi; (5) Memantau kemajuan belajar peserta didik melalui guru sesering mungkin berdasarkan data prestasi belajar; (6) Menyelenggarakan pertemuan secara aktif, berkala dan berkesinambungan dengan komite sekolah, guru, dan warga sekolah lainnya mengenai topik-topik yang memerlukan perhatian; (7) Membimbing dan mengarahkan guru dalam memecahkan masalah-masalah kerjanya, dan bersedia memberikan bantuan secara proporsional dan professional; (8) Mengalokasikan dana yang diperlukan untuk menjamin pelaksanaan program pembelajaran sesuai prioritas dan peruntukkannya; (9) Melakukan berbagai kunjungan kelas untuk mengamati kegiatan pembelajaran secara langsung; (11)Memberikan dukungan kepada para guru untuk menegakkan disiplin peserta didikk; (12) Memperhatikan kebutuhan peserta didik, guru, staf, orang tua, dan masyarakat sekitar sekolah; (13) menunjukkan sikap dan perilaku teladan yang dapat menjadi panutan atau model bagi guru, peserta didik, dan seluruh warga sekolah; (14) Memberikan kesempatan yang luas kepada seluruh warga sekolah dan masyarakat untuk berkonsultasi dan berdiskusi mengenai permasalahan yang dihadapi berkaitan dengan pendidikan dan pembelajaran di sekolah; (15) Mengarahkan perubahan dan inovasi dalam organisasi; (16) Membangun kelompok kerja aktif, kreatif, dan produktif; (17) Menjamin kebutuhan peserta didik, guru, staf, orangtua, dan masyarakat sebagai pusat kebijakan; (18) Memiliki komitmen yang jelas terhadap penjaminan mutu lulusan; (19) Memberikan ruang pemberdayaan sekolah kepada seluruh warga sekolah.

\footnotetext{
${ }^{1}$ Hasil wawancara dengan Mashuri Wakil Kepala Sekolah Bidang Kurikulum, Sabtu 7 Juli 2018.
} 
Jurnal Politik dan Pemerintah Daerah, 1 (2), 2019 - 79

Ade Satria, Siti Maryam

“Wawancara menurut Elidayanti bahwa kepemimpin harus meningkatkan kedisplinan terhadap kinerja guru agar guru tidak terlabat lagi dalam menjalankan kinerja sehingga siswa dapat belajar dengan lancar dengan meningkatkan disiplin kerja terhadap guru dan siswa SMKN 3 Muara Bungo. ${ }^{2}$

Berdasarkan hasil wawancara tersebut dapat disimpulkan bahwa kepemimpinan kepala sekolah harus ditingkatkan lagi supaya kedisiplinan dan kinerja guru tidak terhambat lagi, supaya guru dapat mengajarkan siswa dan meningkatkan kedisiplinan kerja guru tersebut.

Disiplin merupakan pengendalian diri karyawan dan pelaksanaan yang teratur dan menunjukan tingkat kesungguhan tim kerja di dalam sebuah organisasi. Disiplin itu mempunyai tiga aspek, yaitu: Pertama, Sikap mental (mental attitude) yang merupakan sikap taat dan tertib sebagai hasil atau pengembangan dari latihan, pengendalian pikiran dan pengendalian watak. Kedua, Pemahaman yang baik mengepai sistem aturan perilaku, norma, kriteria dan standar yang sedemikian rupa sehingga hal tersebut menumbuhkan pengertian yang mendalam atau kesadaran, bahwa ketaatan akan aturan norma, kriteria dan standar tadi merupakan syarat mutlak untuk mencapai keberhasilan (sukses). Ketiga, Sikap kelakuan yang secara wajar menunjukkan kesungguhan hati, untuk mentaati segala hal secara cermat dan tertib.

"Wawancara menurut mohd jamil bawah kepemimpin di SMKN 3 tidak adanya kerja sama antara bawahan dengan pemimpin dan perlu meningkatkan kerja sama terhadap pemimpin dengan bawahan. ${ }^{3}$

Berdasarkan hasil wawancara tersebut dapat disimpulkan bahwa Selama Kepemimpinan Kepala Sekolah ini tidak adanya kerja sama antara atasan dan bawahan oleh karena itu harus ada kerja sama antara atasan sama bawahan tersebut.

\section{Faktor-faktor yang Mempengaruhi Kedisiplinan}

Hasibuan mengemukakan bahwa faktor-faktor yang mempengaruhi kedisiplinan adalah sebagai berikut: Pertama, Tujuan dan kemampuan. Tujuan dan kemampuan ini mempengaruhi tingkat kedisiplinan karyawan. Tujuan yang akan dicapai harus jelas dan ditetapkan secara ideal serta cukup menantang bagi kemampuan karyawan. Kedua, Teladan pimpinan Teladan pimpinan sangat berperan dalam menentukan kedisiplinan pegawai karena pimpinan dijadikan teladan dan panutan oleh para bawahannya. Pimpinan harus memberikan contoh yang baik, berdisiplin baik; Ketiga, jujur, adil serta sesuai kata dengan perbuatannya. Dengan keteladanan pimpinan yang baik, kedisiplinan bawahan pun akan ikut baik. Keempat, Balas Jasa Balas jasa (gaji, kesejahteraan) ikut mempengaruhi kedisiplinan karyawan, karena balas jasa akan memberikan kepuasan dan kecintaan karyawan terhadap perusahaan. Jika kecintaan karyawan semakin tinggi terhadap pekerjaan, kedisiplinan akan semakin baik. Untuk mewujudkan kedisiplinan karyawan yang baik perusahaan harus memberikan balas jasa yang relatif besar (Hasibuan, 2008, p. 195). Kelima, Keadilan Keadilan ikut mendorong terwujudnya kedisiplinan pegawai, karena ego dan sifat manusia yang selalu merasa dirinya penting dan minta diperlakukan sama dengan manusia lainnya. Keadilan yang dijadikan dasar kebijaksanaan dalam pemberian balas jasa atau hukuman akan merangsang terciptanya kedisiplinan pegawai yang baik. Keenam, kemanusiaan yang serasi diantara semua karyawan. Kedisiplinan karyawan akan tercipta apabila hubungan kemanusiaan dalam organisasi tersebut baik. Ketujuh, Waskat (Pengawasan Melekat) Waskat adalah tindakan nyata paling efektif dalam mewujudkan kedisiplinan karyawan perusahaan. Dengan waskat berarti atasan harus aktif dan langsung mengatasi perilaku, moral, sikap, gairah kerja dan prestasi kerja bawahannya Dengan waskat, atasan secara langsung dapat mengetahui kemampuan dan kedisiplinan setiap individu bawahannya sehingga konduite setiap bawahan dinilai objektif. Jadi waskat menuntut adanya kebersamaan aktif antara pimpinan dan pegawai dalam mencapai tujuan organisasi. Kedelapan, Sanksi Hukuman Sanksi hukuman berperan penting dalam memelihara kedisiplinan pegawai. Dengan sanksi hukuman yang semakin berat, pegawai akan semakin takut melanggar peraturan-peraturan organisasi, sikap dan perilaku indisipliner pegawai akan berkurang. Berat/ringan sanksi hukuman yang akan diterapkan itu mempengaruhi baik buruknya kedisiplinan

\footnotetext{
${ }^{2}$ Hasil wawancara dengan Elidayanti Wakil Kepala Sekolah Bidang Kesiswaan, Sabtu 7 Juli 2018.

${ }^{3}$ Hasil wawancara dengan Mohd Jamil, Kasubag Tata Usaha SMK Negeri 3 Muara Bungo, Sabtu 7 Juli 2018.
} 
Jurnal Politik dan Pemerintah Daerah, 1 (2), 2019 - 80

Ade Satria, Siti Maryam

pegawai. Sanksi hukuman harus ditetapkan berdasarkan pertimbangan logis, masuk akal dan diinformasikan secara jelas kepada semua pegawai. Kesembilan, Ketegasan Ketegasan pimpinan dalam melakukan tindakan akan mempengaruhi kedisiplinan karyawan perusahaan, pimpinan harus berani dan tegas bertindak untuk memberikan sanksi sesuai dengan yang telah ditetapkan perusahaan sebelumnya. Dengan demikian pimpinan akan dapat memelihma kedisiplihan karyawan perusahaan. Kesepuluh, Hubungan Kemanusiaan Hubungan kemanusiaan yang harmonis diantara sesama karyawan ikut menciptakan kedisiplinan yang baik pada suatu perusahaan. Manajer harus berusaha menciptakan suasana hubungan

"Wawancara $m$ lazimi di smk negri 3 muara bungo kepemimpinanya sangat demokratis dan otoriter ,kepemimpinan yang sangat efektif dalam penentuan kebijakan agar proses pembelajaran yang diselengarakan pada satuan pendididk dapat memberikan jaminan, proses pembelajaran yang berkualitas dan mutu lulusan yang komperatif ${ }^{4}$.

Berdasarkan hasil wawancara tersebut dapat disimpulkan bahwa Kepemimpinan Kepala Sekolah itu menggunakan gaya demokratis dan otoriter karena sangat efektif dalam menentukan kebijakan supaya kebijakan tersebut dapat membuahkan hasil yang sangat berkualitas dan mutu lulusan komperatif.

Kinerja merupakan semua tindakan/prilaku yang di kontrol oleh individu dan memberikan kontribusi bagi pencapaian tujuan.atau prestasi kerja secara kualitas dan kuantitas yang dicapai seseorang dalam melaksanakan tugas sesuai dengan tanggung jawab yang di berikan kepadanya

Kinerja guru dapat dinilai dari aspek kemampuan dasar yang harus dimiliki oleh seoarang guru, yang di kenal denagan istilah "Kopetensi Guru". Menurut Suryonsubroto (2009) kopentensi guru meliputi hal-hal berikut: (1) Penguasaan bahan atau materi pembelajaran; (2) Mengelola program; (3) Mengelola kelas; (4) Mengunakan media/sumber daya pembelajaran; (5) Menguasai landasan kependidikan; (6) Mengelola interaksi belajar mengajar; (7) Menilai prestasi siswa.

Kinerja guru menjadi kunci dalam pengikatan mutu pembelajaran, karenaguberada pada garis terdepan di titik sentral dari setiap usaha reformasi pendidikan yang diarahkan pada perubahanperubahan kualitatif. Setiap usaha peningkatan mutu kinerja guru tidak terlepas dari perubahan kurikulum, pengembangan metode-metode pembelajaran, penyediaan sarana prasarana.

Dari hasil wawanncara tersebut dapat dianalisiskan bawah pengaruh gaya kepemimpinan di SMKN 3 Muara bungo menggunakan 2 gaya kepemimpinan yaitu gaya demokrasi dan gaya otoriter atau otokrasi. Dalam hal ini sesuai wawancara yang dilakukan oleh peneliti. Adapun petikan wawancara sebagai berikut: ....

"Dalam meningkatkan kinerja guru, saya menggunakan 2 gaya kepemimpinan, yaitu gaya demokrasi dan gaya otoriter. Tidak semua yang dilakukan menggunakan gaya kepemimpinan demokrasi, gaya kepemimpinan otoriter yang gunakan apabila terdapat permasalahan yang mendesak, akan tetapi tetap gaya kepemimpinan demokrasi yang paling dominan" 5

Dari hasil wawancara dapat disimpulkan bahwa kepemimpinan SMKN 3 Muara Bungo menggunakan dua gaya kepemimpinan yaitu gaya kepemimpinan demokrasi dan gaya kepemimpinan otoriter (otokrasi). Dalam hal ini gaya yang diterapkan lebih dominan pada gaya kepemimpinan demokrasi karena gaya demokrasi kepemimpinan lebih flexibel dalam menghadapi permasalahan kinerja guru dan kedisiplinan kepemimpinan lebih mementingkan kepentingan bersama daripada kepentingan sendiri, sehingga terciptalah hubungan dan kerjasama yang baik, harmonis, saling membantu di dalam melaksanakan tugas sehari-hari dan akan tercipta suasana yang sehat. Akan tetapi apabila ada suatu permasalahan yang mendesak, maka gaya kepemimpinan,kedisplinan kinerja guru di SMK 3 Muara Bungharus memahami tugas yang harus dilaksanakan sebagai seorang pendidik dan masih memerlukan petunjuk dari kepemimpinan serta belum bisa menentukan apa yang harus (baik) untuk dikerjakan. Sedangkan untuk mengetahui faktor pendukung gaya kepemimpinan tersebut maka diperlukan suatu penilaian. Dalam hal ini hasil wawancara antara kepemimpinan dengan peneliti, yaitu:

\footnotetext{
${ }^{4}$ Hasil wawancara dengan M.Lazimin, Siswa Kelas III Tata Busana SMKN 3 Muara Bungo, Sabtu 7 Juli 2018.

${ }^{5}$ Hasil wawancara dengan Dinda Emilia Triyanti, Ketua Program Jurusan Tata Busana, Sabtu 7 Juli 2018.
} 
"Pada awal saya menjabat menjadi seorang pemimpin SMKN 3 Muara Bungo banyak guru yang sering meninggalkan kelas tanpa izin dan sering tidak masuk tanpa izin,dan sering terlambat,tetapi setelah saya telusuri saya memutuskan untuk melakukan penilaian dengan supervisi kelas dan supervisi klinis dengan teknik observasi kelas karena menurut saya itu sudah memenuhi dalam pembinaan, keteladanan dan dapat mengevaluasi kinerja guru dan tidak lupa dari semua itu tetap disertai hubungan yang murni (kekeluargaan) dan silaturrahmi yang diadakan 2 bulan sekali agar terjadi tegur sapa antara guru dengan guru lainnya"

Berdasarkan hasil wawancara tersebut dapat disimpulkan bahwa Masih Banyaknya guru yang sering meninggalkan kelas disaat mengajar dan tidak meminta izin kepada kepala sekolah/pimpinan dan juga masih sering terlambat datang kesekolah,oleh karena itu kepala sekolah memutuskan untuk melakukan penilaian dan supervisi ke dalam kelas karena menurut kepala sekolah / atasan itu sudah termasuk kedalam pembinaan, dan mengevaluasi kinerja guru tersebut, supaya ada tegur sapa antara kepala sekolah/atasan dengan guru dan pegawai yang ada di Sekolah tersebut.

Meskipun kepemimpinan menerapkan gaya kepemimpinan demokrasi, sikap disiplin harus tetap diterapkan, karena akan mempengaruhi kinerja guru. Apabila pemimpin mendapati guru yang tidak melaksanakan tugas sebagaimana mestinya, pemimpin akan menegur dengan cara baik-baik yaitu dengan mengajak sharing dan terus memberi motivasi. Apabila dengan cara demokrasi guru tetap tidak melakukan perubahan terhadap dirinya, maka pemimpin memberikan teguran dan tidak mengulang lagi.

Pembahasan: Analsis Pengaruh Gaya Kepemimpinan Terhadap Kedisiplinan dan Kinerja Guru SMK N 3 Muara Bungo

Pengaruh gaya kepemimpinan terhadap kenerja guru hasil pengujian hipotesis mendukung adanya pengaruh langsung gaya kepemimpinan terhadap kinerja guru di SMK Negeri 3 Muara Bungo Kabupaten Bungo. Ini mengandung arti bahwa baik atau buruknya gaya kepemimpinan yang diterapkan berpengaruh lansung terhadap tinggi atau rendahnya kinerja para guru. Semakin baik gaya kepemimpinan kepala sekolah semakin tinggi kinerja para guru. Sebalinya semakin buruk gaya kepemimpinan akan semakin rendah kinerja para guru.

"Menurut wawancara Dwi sulistiawati dalam melaksanakan kinerja guru pemimpin bertanggung jawab terhadap bawahan dan pemimpin harus meningkatkan kedisplinan kerja dan banyak memberi motivasi terhadap guru ${ }^{7}$

Berdasarkan hasil wawancara tersebut dapat disimpulkan bahwa Kepala Sekolah harus bertanggung jawab kepada guru dan pegawai yang ada di sekolah, supaya meningkatkan kedisiplinan kerja dan kepala sekolah juga harus memberikan motivasi kepada guru yang ada di sekolah tersebut.

Pembahasan: Analsis Pengaruh sikap guru dengan kinerja guru SMK N 3 Muara Bungo

Pengaruh Gaya Kepemimpinan Terhadap Kenerja Guru Hasil pengujian hipotesis mendukung adanya pengaruh lansung gaya kepemimpinan terhadap kinerja guru di SMK Negeri 3 Muara Bungo Kabupaten Bungo. Artinya, baik buruknya sikap guru akan berpengaruh langsung terhadap kinerjanya. Temuan mengandung implikasi bahwa kinerja guru dapat ditingkatkan dengan dukungan sikap guru yang tanggap terhadap lingkungannya, terutama di sekolah

"Wawancara Rekha bianti bahwa di smk $n 3$ muara bungo ini sangat banyak tidak ada hubungan yang erat terhadap pemimpin sehingga pemimpin yang kurang nya efektif terhadap bawahan menimbulkan tidak kesesuaian. ${ }^{8}$

Berdasarkan hasil wawancara tersebut dapat disimpulkan bahwa masih banyak yang tidak ada hubungan yang erat kepada kepala sekolah/atasan sehingga kepala sekolah kurang efektif kepada guru dan pegawai dan menimbulkan ketidak pahaman dan kesesuaian antara kepala sekolah dan guru.

\footnotetext{
${ }^{6}$ Hasil wawancara dengan sepriadi erman Kepala Sekolah, Jumat 6 Juli 2018.

${ }^{7}$ Hasil wawancara dengan Dwi sulistiawati Ketua Program Tata Boga SMKN 3 Muara Bungo, Sabtu 7 Juli 2018.

${ }^{8}$ Hasil wawancara dengan Rekha Bianti Staf Tata Usaha SMKN 3 Muara Bungo, Sabtu 7 Juli 2018.
} 
Jurnal Politik dan Pemerintah Daerah, 1 (2), 2019 - 82

Ade Satria, Siti Maryam

Pembahasan: Analisis Pengaruh Kedisiplin Guru terhadap Kineja Guru SMK Negeri 3 Muara Bungo

Pengaruh Disiplin Guru terhadap Kineja Guru Hasil pengujian hipotesis mendukung adanya pengaruh langsung antara disiplin guru dengan kinerja guru. Hal ini juga sesuai dengan teoritis bahwa disiplin adalah ukuran dari keberhasilan dalam menjalankan tugas demi mencapai tujuan secara maksimal. Seorang guru yang terbiasa disiplin akan semakin berkualitas kinerjanya dan yang lebih penting lagi kedisiplinan guru hendaknya menjadi teladan bagi peserta didiknya.

\section{Gambaran Disiplin Kerja Guru di SMK N 3 Muara Bungo}

Sumber Daya Manusia yang memiliki disiplin yang baik merupakan unsur penting dalam suatu organisasi. Kedisiplinan itu sangat penting dalam peningkatan kinerja seseorang, sebab dengan disiplin maka semua tugas akan dapat selesai dengan baik dan tepat waktu. Gambaran disiplin guru yang meliputi kehadiran guru di sekolah sudah sesuai dengan jadwal tugas dan harapan, masuk dimulai dari 7.30, dan toleransi 15 menit, dan masih banyak guru yang pulang sebelum jam 13.50, mempertimbangkan jarak tempuh guru ke sekolah. Selanjutnya kepatuhan terhadap aturan, guru adalah sudah cukup baik, guru contoh bagi siswa, jadi guru harus menjadi tauladan bagi siswa. Produktivitas kerja, sejauh ini produktivitas yang dilakukan guru sudah baik, guru-guru sudah maksimal dalam melaksanakan tugas, dari siswa yang dulunya tidak mencapai 300 orang sekarang sudah 720 orang. Dulunya yang lulus tidak 100\%, tetapi beberapa tahun ini kelulusan sudah 100\%. "Guru yang disiplin dapat diartikan sebagai guru yang mentaati aturan yang dibuat oleh sekolah". Disiplin yang mantap pada hakekatnya akan tumbuh dan terpancar dari hasil kesadaran manusia. Disiplin yang tidak bersumber dari hati nurani manusia akan menghasilkan disiplin yang lemah dan tidak tahan lama.

"Wawancara menurut lisda nazif pemimpin harus meningkatkan kedisplinan yang sangat prevetif dalam meningkat pelanggaran terhadap bawahan sehingga setiap pelanggaran yang dilakukan bawahan, pemimpin menegur secara lisan agar tidak terjadinya lagi tindakan yang melanggar ke disiplinan. ${ }^{9}$

Berdasarkan hasil wawancara tersebut dapat disimpulkan bahwa Kepala sekolah harus meningkatkan kedisiplinan yang sangat prevatif supaya tidak ada guru yang melanggar kedisiplinan di sekolah dan kepala sekolah itu harus menegur guru yang melanggar hal tersebut supaya tidak ada lagi yang melanggar kedisiplinan dan sekolah menjadi sekolah yang disiplin mulai dari guru,pegawai dan siswa harus disiplin.

\section{Hambatan-Hambatan Gaya kepemimpinan, kedisiplinan dan kinerja Guru SMK N 3 Muara Bungo}

Hambatan yang dialami kepemimpinan adalah masing-masing guru mempunyai karakter yang berbeda, ada yang rajin, dan komitmen terhadap aturan yang telah dibuat bersama. Namun masih ada guru yang tidak komitmen, seperti ketika ditugaskan menjadi pembina upacara, selalu menghindar dengan berbagai alasan. Menurut Ambarita mengatakan bahwa, "disiplin pada dasarnya merupakan tindakan manajemen, untuk mendorong agar para anggota organisasi dapat memenuhi berbagai ketentuan dan peraturan yang berlaku dalam satu organisasi, yang di dalamnya mencakup: (1) adanya tata tertib atau ketentuanketentuan; (2) adanya kepatuhan para pengikutnya; (3) adanya sanksi bagi pelanggar

Kesadaran adalah sikap seseorang yang secara sukarela mentaati semua peraturan dan sadarakan tugas dan tanggung jawabnya, kesediaan adalah sikap, tingkah laku, dan peraturan perusahaan, baik yang tertulis maupun tidak (Ambarita, 2015, p. 148).

“Wawancara menurut Dinda Emilia untuk meningkatkan kinerja Guru pemimpin harus berkerja sama dengan bawahan sehingga kinerja guru berjalan dengan baik. ${ }^{10}$

\footnotetext{
${ }^{9}$ Hasil wawancara dengan Lisda Nazif Ketua Program Multimedia SMKN 3 Muara Bungo, Sabtu 7 Juli 2018.

${ }^{10}$ Hasil wawancara dengan Dinda Emilia Triyanti Ketua Program Tata Busana SMKN 3 Muara Bungo, Sabtu 7 Juli 2018.
} 
Jurnal Politik dan Pemerintah Daerah, 1 (2), 2019 - 83

Ade Satria, Siti Maryam

Berdasarkan hasil wawancara tersebut dapat disimpulkan bahwa Kepala Sekolah Harus bekerja sama dengan guru, supaya dalam meningkatkan kinerja guru berjalan dengan baik dan sesuai apa yang di inginkan guru tersebut.

\section{Upaya kepemimpinan Mempengaruhi Guru Dalam Meningkatkan Disiplin Dan Kinerja Guru di SMK Negeri 3 Muara Bungo}

Kepemimpinan memiliki tanggung jawab untuk mempengaruhi guru, untuk bekerja/ berperan serta guna mencapai tujuan yang ditetapkan. Upaya yang dilakukan adalah dengan cara memberikan contoh. Pertama, memberikan keteladan kepada bawahan, seperti datang lebih awal ke sekolah, disiplin dalam berpakaian, tepat waktu masuk kelas untuk melaksanakan proses belajar mengajar. Kedua, Menjalin komunikasi yang baik kepada guru dan staf tata usaha, menyempatkan diri pada waktu istrirahat, untuk menyapa, atau berdiskusi, dan memberikan pencerahan, serta semangat agar dapat berkerja dan berbuat yang terbaik demi kemajuan sekolah.

Dengan memberikan contoh atau tauladan, untuk mempengaruhi guru, karena aturan sebagus apapun dibuat oleh seorang pimpinan tidak akan berhasil, jika pimpinan tersebut tidak memberikan keteladan kepada bawahan. "kepemimpinan adalah proses untuk mepengaruhi orang lain untuk memahami dan setuju dengan apa yang perlu dilakukan dan bagaimana tugas itu dilakukan secara efektif, serta proses untuk memfasilitasi upaya individu dan kolektif untuk mencapai tujuan bersama". Seorang pemimpin dapat mempengaruhi guru dengan menanamkan kebiasaan-kebiasan yang positif.

"Wawancara menurut Mohd Jamil Kepala Sekolah adalah seorang manager/leader ( pemimpin) di suatu sekolah kalau sebagai leader dia tidak bagus, itu akan berdampak pada kinerja dan disiplin guru, Guru tidak ada rasa hormat dan segan kepada kepala sekolah sehingga mengakibatkan guru banyak yang tidak melaksanakan tugas dengan baik, Masuk tidak tepat waktu dan banyak meninggalkan tugas kepada siswa, sebagai Leader Kepala Sekolah harus memenuhi kebutuhan sarana dan prasarana guru untuk menunjang kinerjanya sebagai guru. Bukan malah membatasi kebutuhan guru, dengan kata lain jika kepala sekolah baik kepada warga sekolah maka akan berimbas pada perkembangan dan kekeluargaan disekolah tersebut, tapi jika kepala sekolah tidak baik maka dilingkungan warga sekolah banyak sekali terjadi pertentangan dan mencari menang sendiri. ${ }^{11}$

Berdasarkan hasil wawancara tersebut dapat disimpulkan bahwa Kepala Sekolah harus menjadi contoh atau pigur yang baik supaya guru mengikuti kebaikan tersebut dan masih banyak juga guru yang meninggalkan tugas di dalam kelas dan masuk tidak tepat waktu, karena masih rendahnya sarana dan prasarana di sekolah untuk menunjang kinerja guru kepala sekolah harus memenuhi kebutuhan guru, dan tidak membatasi kebutuhan karena kalau membatasi kebutuhan guru akan mengakibatkan pada perkembangan sekolah, dan kepala sekolah itu harus royal dengan guru supaya tidak adanya pertentangan.

\section{SIMPULAN}

Berdasarkan hasil penelitian dan pembahasan dalam menganalisis gaya kepemimpinan kepala sekolah terhadap Kedisiplinan dan kinerja guru di SMK Negeri 3 Muara Bungo, maka dapat ditarik kesimpulan sebagai berikut: Pertama, Gaya kepemimpinan kepala sekolah di SMK Negeri 3 Muara Bungo mengarah pada gaya kepemimpinan demokratis. Hal tersebut terlihat saat kepala sekolah dalam memimpin rapat, mengambil sebuah keputusan dan menjalankan tugas secara bersama-sama, memotivasi guru, memberikan kesempatan guru untuk melanjutkan sekolah dan membantu guru dalam mencarikan solusi dari permasalahnnya. Jadwal piket diberlakukan setiap hari dengan masing masing hari ada guru guru yang piket dengan dimulai datang pukul 07.30 WIB dan pulang pukul 13.50 WIB. Kedua, Pengaruh Gaya Kepemimpinan Terhadap Kinerja Guru Hasil pengujian hipotesis mendukung adanya pengaruh lansung gaya kepemimpinan terhadap kinerja guru di SMK Negeri 3 Muara Bungo Kabupaten Bungo sebab akan mengandung arti baik buruknya kepemimpinan yang diterapkan, dan semakin baik gaya kepemimpinan kepala sekolah semakin tinggi kinerja guru tersebut, dan sebaliknya semakin buruk gaya kepemimpinan kepala sekolah akan semakin mengakibatkan

\footnotetext{
${ }^{11}$ Hasil wawancara dengan Mohd Jamil Kasubag Tata Usaha SMKN 3 Muara Bungo, Sabtu 7 Juli 2018.
} 
rendahnya kinerja guru. Ketiga, Gambaran kerja guru di SMK Negeri 3Muara Bungo sudah baik, sesuai dengan jadwal tugas dan waktu yang ditentukan, yang meliputi kehadiran guru di sekolah sudah sesuai dengan jadwal tugas dan harapan, masuk dimulai dari 7.30, dan toleransi 15 menit. Produktivitas kerja, sejauh ini produktivitas yang dilakukan guru cukup baik dalam melaksanakan tugas, dari jumlah siswa yang dulunya tidak mencapai 300 orang sekarang sudah 720 orang. Keempat, Upaya kepemimpinan Mempengaruhi Guru Dalam Meningkatkan Disiplin Kinerja Guru di SMK Negeri 3 Muara Bungo.adalah dengan melakukan pendekatan secara personal, melalui komunikasi yang baik serta memberikan motivasi kemudian bimbingan dan kesempatan kepada guru untuk dapat menunjukan kemampuannya jika diberi tugas dan tanggung jawab dan selalu patuh terhadap aturan yang telah dibuat bersama.dan kelima, Hambatan-Hambatan Gaya kepemimpinan ,kedisiplinan dan kinerja Guru SMK Negeri 3 Muara Bungo.karakter guru yang berbeda-beda, ada yang rajin, dan komitmen terhadap aturan yang telah dibuat bersama.

\section{DAFTAR PUSTAKA}

Ambarita, B. (2015). OPM declares open war on security forces, non-Papuan civilians. Jakarta: Globe.

Arikunto, S. (2009). Manajemen penelitian. Jakarta: Renika Cipta.

Gaffar, A. (2009). Republik Desa pergulatan hukum tradisional dan hukum modern dalam desain otonomi desa. Bandung: Alumni

Hasibuan, M. S. (2007). Pengertian Kedisiplinan. Jakarta: Bumi Aksara

Kuswana, D. (2011). Metode penelitian sosial. Bandung: Pustaka Setia.

Mulyana, D. (2008). Metode penelitian kualitatif: Paradigma baru ilmu komunikasi dan ilmu sosial lainnya. Bandung: PT Remaja Rosdakarya.

Presiden Republik Indonesia (2003). Undang-Undang Republik Indonesia Nomor 20 Tahun 2003 tentang sistem pendidikan nasional

Republik Indonesia. (2002). Undang-Undang Dasar Republik Indonesia Tahun 1945 Amandemen ke Empat.

Sugiyono, S. (2009). Metode penelitian administrasi. Bandung: Alfabeta.

Sukmadinata, N. S. (2009). Metode penelitian Pendidikan. Bandung, Rejama Rosdakarya.

Suryonsubroto, B. (2009). Proses belajar mengajar di sekolah. Jakarta: PT. Rineka Cipta

Winardi, J. (2002). Motivasi dan pemotivasian dalam manajemen. Jakarta: PT. Raja Grafindo Persada. 